\title{
Partai Politik Lokal di Negara Kesatuan: Upaya Mewujudkan Otonomi Daerah di Bidang Politik
}

\author{
M. Rifqinizamy Karsayuda \\ Fakultas Hukum Universitas Lambung Mangkurat Banjarmasin \\ Jalan Brigjend Hasan Basry Banjarmasin 70123, Telp/Fax (0511) 3305648 \\ rechtolog@yahoo.com
}

\begin{abstract}
A district autonomy as the consequence of UUD 1945 amendment, gives several authorities to the local government, and one of the autonomies is in politics. The local politic parties are expected to be able to apply the political autonomy, even though juridically its existence is still difficult to be conducted by the national party regulation in UU Nomor 2 Tahun 2008 (constitution number 2 year of 2008) about Political Party and UU Nomor 10 Tahun 2008 (constitution number 10 year of 2008) about Public Election. The focuses of this research are; first, what is the theoretical basis in creating the local political party in Indonesia as a united nation? Second, how is the concept of local political party that is relevantly applied in Indonesia as a united nation which is suitable with Indonesian constitutional substance? The method used in this research is the qualitative investigation of law material with the juridical approach which is completed by political approach. This research has concluded; first, the urge of local political party has presented in Indonesia, not only as the consequence of the realization of district autonomy, but also as the implementation of ideology federalism theory which is aimed as the existence guard of a country. Second, a local political party that can be developed in Indonesia, in the future, is a political party that has no relation with a national party, as it is a structure as well as in election.
\end{abstract}

Key words: Local autonomy, unitarian state, local poltical party.

\begin{abstract}
Abstrak
Otonomi daerah sebagai satu konsekuensi dari amandemen UUD 1945 memberikan banyak kewenangan kepada pemerintah daerah, salah satunya otonomi di bidang politik. Partai politik lokal diharapkan dapat mewujudkan otonomi politik tersebut, walau secara yuridis keberadaannya masih sulit diwujudkan dengan adanya aturan kepartaian yang bersifat nasional dalam UU Nomor 2 Tahun 2008 Tentang Partai Politik dan UU Nomor 10 Tahun 2008 Tentang Pemilihan Umum. Fokus penelitian ini, pertama: apa landasan teoritikal untuk melahirkan partai politik lokal di Indonesia yang berbentuk negara kesatuan? Kedua, bagaimanakah konsep partai politik lokal yang relevan diterapkan di Indonesia sebagai negara kesatuan sesuai kaidah hukum tata negara Indonesia? Metode penelitian yang digunakan berupa penulusuran bahan hukum yang bersifat kualitatif dengan pendekatan yuridis yang dilengkapi dengan pendekatan politik. Penelitian ini menyimpulkan, Pertama, urgensi partai politik lokal hadir di Indonesia selain sebagai konsekuensi dari pelaksanaan otonomi daerah juga merupakan implementasi dari teori federalime ideologis yang dihajatkan sebagai penjaga keberagaman dalam suatu negara. Kedua, partai politik lokal yang dapat dikembangkan di Indonesia ke depan adalah partai politik yang tidak punya hubungan sama sekali dengan partai nasional, baik secara struktural, maupun dalam Pemilu.
\end{abstract}

Kata kunci : Otonomi daerah, negara kesatuan, partai politik lokal. 


\section{Pendahuluan}

Selama tiga puluh dua tahun berada di bawah rezim orde baru, Indonesia mengalami apa yang disebut oleh Karl D. Jason sebagai bereucratic politic (politik birokrasi), yaitu suatu keadaan politik yang menempatkan negara pada kedudukan sangat dominan. ${ }^{1}$ Pada era ini, kekuasaan dalam pembuatan keputusan didominir para penguasa, terutama para perwira militer dan pejabat tinggi birokrasi. ${ }^{2}$

Keadaan demikian dalam teori korporatisme sebagaimana pernah ditulis oleh Moh. Mahfud $\mathrm{MD}^{3}$, negara dipandang sebagai suatu organ yang mempunyai kemauan dan kepentingan sendiri yang dapat melakukan campur tangan dalam kehidupan masyarakatnya. ${ }^{4}$ Kerangka berfikir demikianlah ternyata yang menjadi pandangan penguasa orde baru. Kerangka berfikir tersebut dilatarbelakangi oleh keyakinan bahwa stabilitas politik adalah kunci utama dalam mengejar ketertinggalan dari negara-negara lain, terutama untuk memulai pertumbuhan ekonomi dengan cepat. ${ }^{5}$

Setelah reformasi bergulir yang ditandai dengan lengsernya Soeharto dari kursi kepresidenan, dilakukan berbagai ikhtiar perbaikan bangsa. Salah satu ikhtiar ketatanegaraan yang dilakukan adalah dengan melakukan amandemen terhadap Undang-Undang Dasar (UUD) 1945. Sejak 1998 hingga 2001, terdapat empat kali amandemen terhadap UUD 1945.

Amandemen tersebut menyentuh beberapa persoalan fundamental ketatanegaraan, salah satunya tentang pembagian kekuasaan antara pemerintah pusat (cetral government) dengan pemerintah daerah (local government). Dalam konteks itu, amandemen UUD 1945 melahirkan konsep otonomi daerah. Hal tersebut dapat dilihat dalam Pasal 18 ayat (1), (2) dan (4) UUD 1945 setelah amandemen sebagai berikut : (1) Negara Kesatuan Republik Indonesia dibagi kepada daerah-daerah provinsi dan daerah provinsi itu dibagi pula kepada kabupaten dan kota, yang tiaptiap provinsi, kabupaten dan kota itu mempunyai pemerintahan daerah, yang diatur dengan undang-undang; (2) Pemerintahan daerah provinsi, daerah kabupaten, dan kota mengatur dan mengurus sendiri urusan pemerintahan menurut asas otonomi dan tugas pembantuan; (4) Pemerintah daerah menjalankan otonomi seluas-luasnya,

\footnotetext{
${ }^{1}$ Yahya Muhaimin. “Beberapa Segi Birokrasi di Indonesia”. Majalab Prisma, No.10. Jakarta, 1980, hlm. 47.

${ }^{2}$ Moh. Mahfud, MD., Demokerasi dan Konstitusi di Indonesia, Rineka Cipta, Jakarta 2000, hlm. 105.

${ }^{3}$ Moh. Mahfud, MD., Politik Hukum di Indonesia, Pustaka LP3ES, Jakarta, 1998, hlm. 229.

${ }^{4}$ Ibid., hlm. 229.

${ }^{5}$ Ibid., hlm. 230.
} 
kecuali urusan pemerintahan yang oleh undang-undang ditentukan sebagai urusan Pemerintah Pusat.

Secara lebih terperinci, pembagian kekuasaan antara pemerintah pusat dan pemerintah daerah melalui aturan otonomi daerah diatur dalam Undang-Undang (UU) Nomor 22 Tahun 1999 sebagaimana telah diubah menjadi UU Nomor 32 Tahun 2004 tentang Pemerintahan Daerah dengan beberapa perubahannya di kemudian hari. Dalam Pasal 1 ayat (5) UU No. 32 Tahun 2004 tersebut dijelaskan makna otonomi daerah, yaitu :"otonomi daerah adalah hak, kekuasaan, dan kewajiban daerah otonom untuk mengatur dan mengurus sendiri urusan pemerintahan dan kepentingan masyarakat setempat sesuai dengan peraturan perundang-undangan".

Dalam rangka menjalankan otonomi daerah tersebut, setiap daerah memiliki kekuasaan dalam berbagai bidang, kecuali yang menjadi kekuasaan pemerintah pusat. Kekuasaan pemerintah pusat tersebut ditegaskan dalam Pasal 10 ayat (3) UU Nomor 32 Tahun 2004, yaitu meliputi kekuasaan dalam bidang : a. politik luar negeri; b. Pertahanan; c. Keamanan; d. Peradilan. e. Moneter dan fiskal, dan; f. Agama.

Berdasarkan aturan di atas, otonomi daerah jelas memberikan kekuasaan yang sangat besar kepada setiap daerah. Menurut Jimly Asshiddiqie, otonomi daerah di Indonesia dilihat dari pembagian kekuasaan antara pemerintah daerah dengan pemerintah pusat tidak jauh berbeda dengan di negara yang menganut bentuk federal. ${ }^{6}$ Hal ini dilandaskan pada teori kekuasaan residu (sisa) atau residual power di suatu negara. Di negara-negara federal umumnya, kekuasaan sisa berada di pemerintahan federal (pusat), sementara kekuasaan yang proporsinya lebih banyak justru berada di negara-negara bagian. ${ }^{7}$

Berdasarkan pembagian urusan pemerintahan sebagaimana diatur dalam UU No. 32 Tahun 2004 di atas, maka salah satu otonomi yang dimiliki daerah ialah otonomi dalam bidang politik. Ikhtiar untuk mewujudkan otonomi di bidang politik tersebut dilakukan dengan memberi pengaturan baru tentang Pemilihan Kepala Daerah dan Wakil Kepala Daerah secara langsung, termasuk pengaturan tentang mekanisme pemilihan Anggota Legislatif, seperti DPRD (Provinsi, Kabupaten/Kota) dan DPD yang lebih mendekatkan pemilih dengan si calon yang merupakan wakil dari daerahnya.

\footnotetext{
${ }^{6}$ Jimly Asshiddiqie, Reformasi Hukum Nasional. Makalah Seminar Kelompok Kerja Nasional Reformasi Hukum Menuju Masyarakat Madani, Sekretariat Negara, Jakarta, 1999, hlm. 12.

${ }^{7}$ Finer, S.E.et.al, Comparing Constitutions, Clarendon Press, Oxford, 1995, hlm 134.
} 
Dua mekanisme rekrutmen kepemimpinan daerah di atas secara simbolik menggambarkan telah hadirnya otonomi di bidang politik, karena dipilih langsung oleh penduduk daerah setempat. Otonomi politik itu sesungguhnya belum terwujud, sebab masih terbukanya kemungkinan pintu campur tangan terhadap otonomi politik di daerah oleh pusat. Campur tangan itu hadir seiring dengan masih diterapkannya sistem kepartaian yang bersifat nasional. Akibatnya, partai politik di tingkat nasional sering mengintervensi partai-partai politik di daerah dalam dua mekanisme pemilihan tadi. ${ }^{8}$

Hal inilah yang memunculkan gagasan untuk membentuk partai politik lokal di setiap daerah, selain terdapat beberapa alasan lain yang relevan dikemukakan dalam rangka mendukung gagasan pembentukan partai politik lokal ini, seperti adanya pengalaman historis bangsa ini pada 1955. Partai politik lokal pernah diperkenankan dan mengikuti pemilihan umum pada tahun itu. ${ }^{9}$

Gagasan ini juga dilatarbelakangi oleh diperkenankannya pembentukan partai politik lokal di Provinsi Nanggroe Aceh Darussalaam (NAD) yang diberikan otonomi khusus (special autonomy policy) sebagaimana diperuntukkan dalam UU Nomor 11 Tahun 2006 tentang Pemerintahan Aceh. Pembentukan partai politik lokal di Aceh ini secara emosional mendorong daerah-daerah lain juga menuntut agar dapat membentuk partai-partai politik lokal. ${ }^{10}$

Dalam konteks yuridis, pembentukan partai politik lokal di Indonesia masih terhalang oleh aturan-aturan yang terdapat dalam beberapa peraturan perundangundangan, diantaranya UU No. 2 Tahun 2008 tentang Partai Politik. UU tersebut

${ }^{8}$ Untuk menganalisis lahirnya intervensi tersebut melalui sistem Kepartaian dan Pemilu yang ada dapat dilihat ketentuan dalam Pasal 59 UU No. 32 Tahun 2004 yang menyatakan : Partai politik atau gabungan partai politik sebagaimana dimaksud pada ayat (1) dapat mendaftarkan pasangan calon apabila memenuhi persyaratan perolehan sekurang-kurangnya 15\% (lima belas persen) dari jumlah kursi DPRD atau 15\% (lima belas persen) dari akumulasi perolehan suara sah dalam Pemilihan Umum anggota DPRD di daerah yang bersangkutan. Lihat pula ketentuan Pasal 52 UU No. 2 Tahun 2008 Tentang Partai Politik yang menyatakan : Dalam hal pengajuan calon anggota legislatif berlaku ketentuan sebagai berikut (1) Bakal calon dalam pemilihan umum disusun dalam daftar bakal calon oleh partai politik masing-masing; (2) Daftar bakal calon untuk anggota DPR ditetapkan oleh pengurus Partai Politik di tingkat pusat; (3) Daftar bakal calon anggota DPRD provinsi ditetapkan oleh pengurus Partai Politik di tingkat provinsi; (4) Daftar bakal calon anggota DPRD kabupaten/kota ditetapkan oleh pengurus Partai Politik di tingkat kabupaten/kota.

${ }^{9}$ A.Muktie Fadjar, Partai Politik dalam Perkembangan Sistem Ketatanegaraan Indonesia, in-Trans Publishing, Malang, 2006, hlm. 87.

${ }^{10}$ Salah satu daerah yang getol memperjuangkan lahirnya partai politik lokal ialah Papua. Selain dilatarbelakangi oleh rasa termarjinalkan oleh Republik, Masyarakat Papua juga merasa memiliki kekhasan yang tak dimiliki wilayah lain. Kekhasan itu belakangan mendapat landasan yuridis berupa otonomi khusus, layaknya Naggroe Aceh Darussalaam. Lihat dalam Laurence Sulivan, "Partai Politik Lokal”, Makalah Universitas Cendrawasih, Jayapura, 2003, hlm. 4. 
memuat beberapa peraturan yang belum memungkinkannya dibentuk partai-partai politik lokal, dimana salah satu syarat pembentukan partai politik sebagaimana diatur dalam Pasal 3 huruf d UU No. 2 Tahun 2008 adalah “kepengurusan (partai politikpenulis) paling sedikit 60\% (enam puluh perseratus) dari jumlah provinsi, $50 \%$ (lima puluh perseratus) dari jumlah kabupaten/kota pada setiap provinsi yang bersangkutan, dan 25\% (dua puluh lima perseratus) dari jumlah kecamatan pada setiap kabupaten/kota pada daerah yang bersangkutan".

Aturan lain terdapat dalam Pasal 17 UU No. 2 Tahun 2008 tersebut, yang menegaskan : (1) Organisasi partai politik terdiri atas: a. organisasi tingkat pusat; $b$. organisasi tingkat provinsi; dan c. organisasi tingkat kabupaten/kota. (2) Organisasi partai politik dapat dibentuk sampai tingkat kelurahan/desa atau sebutan lain. (3) Organisasi partai politik sebagaimana dimaksud pada ayat (1) mempunyai hubungan kerja yang bersifat hierarkis.

Aturan serupa juga berlaku bagi partai politik yang hendak mengikuti pemilihan umum sebagaimana diatur dalam UU No.10 Tahun 2008 tentang Pemilihan Umum Anggota DPR, DPD dan DPRD. Pasal 8 ayat (1) huruf b dan c UU No.10 Tahun 2008 menegaskan : "Partai politik dapat menjadi Peserta Pemilu setelah memenuhi persyaratan: b. memiliki kepengurusan di 2/3 (dua pertiga) jumlah provinsi; c. memiliki kepengurusan di 2/3 (dua pertiga) jumlah kabupaten/kota di provinsi yang bersangkutan".

Pada masa mendatang, gagasan mengenai pembentukan partai politik lokal di Indonesia sebagai konsekuensi dilaksanakannya otonomi daerah merupakan hal yang perlu dipersiapkan sejak awal secara akademik. Penelitian ini bermaksud untuk melakukan analisis akademik terhadap dua hal. Pertama, kemungkinan lahirnya partai politik lokal di Indonesia. Kedua, bagaimana konsep dasar partai politik lokal tersebut jika diimplementasikan dalam negara Republik Indonesia yang berbentuk kesatuan.

\section{Rumusan Masalah}

Berdasarkan latar belakang di atas, rumusan masalah dalam tulisan ini adalah, Pertama: apa urgensi melahirkan partai politik lokal di Indonesia yang berbentuk negara kesatuan? Kedua, bagaimanakah konsep partai politik lokal yang relevan diterapkan di Indonesia sebagai negara kesatuan? 


\section{Tujuan Penelitian}

Penelitian ini bertujuan pertama, untuk mengetahui landasan teoritikal untuk melahirkan partai politik lokal di Indonesia yang berbentuk negara kesatuan, dan kedua, untuk mengetahui konsep partai politik lokal yang relevan diterapkan di Indonesia sebagai negara kesatuan.

\section{Metode Penelitian}

Tulisan ini memfokuskan kajian terhadap pembentukan konsep partai politik lokal di Indonesia dari perspektif ketatanegaraan. Untuk itu, bahan hukum yang digunakan adalah bahan hukum primer dan bahan hukum sekunder. Bahan hukum primer tersebut terdiri dari; UUD 1945, Undang-undang dan berbagai peraturan perundang-undangan terkait lainnya. Sedangkan bahan hukum sekunder ialah bukubuku ilmiah yang berhubungan dengan tulisan ini. Selain itu, makalah, jurnal, majalah dan tulisan ilmiah di berbagai media yang berhubungan langsung dengan pembahasan juga digunakan sebagai bahan hukum sekunder dimaksud.

Adapun teknik pengumpulan bahan hukum yang digunakan kajian literatur atau kepustakaan. Teknik ini dilakukan dengan cara meneliti, mempelajari dan menganalisis secara cermat terhadap bahan-bahan hukum primer dan sekunder di atas. Dalam tulisan ini, analisis bahan hukum dilakukan dengan menggunakan metode kualitatif. Metode ini dimualai dengan data yang dihimpun dengan cara diuraikanan di atas, kemudian diolah dengan cara data diseleksi, diklasifikasikan secara sistematik, logik dan yuridis untuk mendapatkan gambaran umum untuk mendukung tulisan ini.

Pendekatan yang digunakan dalam penyelidikan ini adalah pendekatan legalistik, khususnya dari perspektif hukum tata negara, walaupun dalam beberapa pembahasan ia juga melibatkan beberapa pendekatan lain seperti, ilmu politik. Namun, pembahasan tersebut digunakan hanyalah sebagai pelengkap kajian utama tersebut. 


\section{Hasil dan Pembahasan}

\section{Konsep Dasar Federalisme}

Untuk menganalisis sejauhmana kemungkinan lahirnya partai-partai politik lokal- yang umumnya hadir di negara federal- dapat dibentuk di negara kesatuan, maka perlu diuraikan konsep dasar tentang federalisme itu sendiri yang ternyata tidak seluruhnya merujuk pada pemaknaan sebagai negara berbentuk federal sebagaimana banyak dipahami selama ini. ${ }^{11}$

Menurut Preston King, bentuk negara federal dalam konsepnya sering dipertentangkan dengan teori kedaulatan. ${ }^{12}$ Teori kedaulatan sendiri dipopulerkan oleh Jean Bodin, Thomas Hobbes, Spinoza dan Austin. ${ }^{13}$ Bagi para penggagas konsep kedaulatan, ia adalah sesuatu yang bersifat asli, tertinggi dan tidak dapat dibagibagi. Dalam konteks hubungan antara pemerintahan pusat dengan daerah, kedaulatan hendaknya tidak terbagi-bagi, baik ia berada pada pemerintahan pusat, maupun daerah. Disinilah kritik terhadap konsep federal timbul oleh banyak kalangan.

Prodount, seorang pakar politik dari Perancis adalah orang yang pertama mengemukakan konsep federal ini. ${ }^{14}$ Secara teoritis, Istilah yang berhubungan dengan federalisme biasanya disebutkan dalam dua istilah, iaitu federalisme itu sendiri dan federal (federation). Friderich mengartikan federalisme sebagai satu kesatuan yang tetap menghargai perbedaan dalam kesatuan itu. Ia menyatakan : "Federalism as a union groups, united by one or more common objectives, but retaining their distinctive group character for other purposes". ${ }^{15}$

Istilah federal, rata-rata diartikan sebagai bentuk pemerintahan yang terdiri dari dua atau lebih unit pemerintahan yang bersatu untuk membentuk satu pemerintahan yang lebih besar. Istilah seperti ini dapat dilihat dari kesimpulan pandangan Freeman sebagaimana dinyatakan oleh Burger. Ia menyatakan: " Federation was a mechanism of compromise between two opposing political forces under any of these three classes of

\footnotetext{
${ }^{11}$ Preston King, Federalism and Federation, Croom Helm Press, London, 1982, hlm. 135.

${ }^{12}$ Ibid.

${ }^{13}$ S.F.Marbun, Dimensi-Dimensi Pemikiran Hukum Administrasi Negara, UII Press, Yogyakarta, 2002, hlm. 26.

${ }^{14}$ Gagasan federal Proundhon dituliskan dalam bukunya Du Principle federative et de la necesitte de reconstituer le part de la revolution, Paris, 1863 dalam Preston King, Op.Cit., hlm 20.

${ }^{15}$ C.F. Frederich, New Tendencies in Federal Theory and Practice, Sixth World Congress of IPSA, Genewa, 1964, $h \operatorname{lm} 2$.
} 
government. It was an intermediate state that combined the advantages of the large statepeace, orderand general well-being - with those of the small state - the full development and authonomy of the individual citizen". ${ }^{16}$

Dua pandangan besar atas federalisme itu dalam perkembangannya membagi definisi federalisme oleh para pakar. Setidak-tidaknya ada dua pendapat tentang federalisme, yang pertama adalah yang menganggap federalisme sebagai ideologi dan yang kedua yang melihat federalisme sebagai sebuah institusi.

Dalam pandangan kelompok yang pertama, federalisme dimaknai sebagai sebuah doktrin yang menyokong adanya penerimaan terhadap keberagaman (diversity) dalam sebuah negara demi kesatuan (unity) negara tersebut. Kelompok pertama ini melihat konsep federal sebagai sesuatu yang lebih lunak dan bersifat ideologis. Pendukung pandangan ini diantaranya adalah A. Marc dan Bernard Voyenee. Para pengikut pandangan ini sering mendefinisikan gagasan tentang federal sebagai aliran tentang keberagaman pada suatu negara. ${ }^{17}$

Kelompok kedua beranggapan bahwa federalisme adalah bentuk negara federal itu sendiri. Dalam pandangan kelompok ini, federalisme adalah pembagian kekuasaan yang tegas antara pemerintah pusat dengan daerah dan diformulasikan dalam bentuk yang baku berupa negara federalsebagai lawan dari negara kesatuan yang pada umumnya ditegaskan dalam Kosntitusi.

Para pendukung pandangan ini di antaranya R. Aron dan H. Brugmans, serta Duerlien. Pandangan kelompok kedua ini lebih tepat dipandang sebagai pandangan terhadap federation atau bentuk negara federal itu sendiri sebagaimana yang lazim dipahami banyak orang pada hari ini. ${ }^{18}$ Dalam pandangan kelompok ini, federalisme tidak akan mungkin ada, tanpa didahului adanya negara federal itu sendiri yang termaktub dalam konstitusi negara tertentu. Dengan kata lain, dalam negara kesatuan tidak akan terwujud sama sekali unsur federalisme.

Hal yang berbeda jelas dianut oleh kelompok paham federalisme ideologis. Bagi mereka federalisme sebagai sebuah doktrin tidak mesti diwujudkan dalam bentuk negara persekutuan. Doktrin federalisme yang meletakkan penghargaan terhadap keanekaan dapat pula diamalkan dalam konteks negara kesatuan. Dalam konteks

\footnotetext{
${ }^{16}$ Michael Burger, Comparative Federalism; Theory and Practice, Routledge Taylor \& Francis Group, London, 2006, hlm. 13.

${ }^{17}$ Preston K., Op.Cit, hlm 23.

${ }^{18}$ Ibid., hlm. 25.
} 
itulah, para penganut paham pertama ini membagi federalism pada tiga jenis berdasarkan orientasinya, yaitu federalisme yang bersifat sentralistik (centralistic federalism), desentralistik (decentralistic federalism) dan yang bersifat berimbang (balanced federalism). ${ }^{19}$

Bagi para pengikut pandangan federalisme ideologis, istilah federalisme ialah merujuk pada bentuk federalisme sebagai sebuah ideologi. Ia merupakan sesuatu yang dikontruksikan sebagai sebuah doktrin. Alexander Marc mengatakan bahwa "federalism became a doctrine" pada abad kesembilan belas. Bahkan P.J. Prodhount sebagai peletak dasar teori-teori tentang federal menyatakan "truth is one" (percaya pada idea persekutuan ini)". Kata truth menurut King diartikan Proudont bertujuan menjadikan gagasannya tentang federalisme dapat dijadikan sebagai satu-satunya doktrin dan kemudian dapat dirumuskan dalam Konstitusi-Konstitusi di pelbagai negara. $^{20}$

Bagi Prodount, gagasan tentang federalisme yang ditawarkannya masa itu lebih diartikan sebagai nilai-nilai federalisme yang berisi pentingnya penghargaan terhadap daerah-daerah oleh pemerintah pusat. Prodount sebagai penemu teori federalisme tidak menyebut bahaa federalisme mesti dilakukan dengan membentuk negara federal. Ia mengatakan "the sole constitution which an astringent reason will compel the peoples of the world to adopt is federalism".

Sebagai penerus gagasan Prodount, Marc menyatakan bahwa federalisme merupakan sebuah ideologi yang akan membawa kepada kebangkitan revolusioner. Marc meletakkan gagasan federalisme sebagai jalan keluar yang konstruktif untuk menyatukan seluruh aktivitas, masalah dan pelbagai keinginan manusia. Menurut Marc federalisme dapat mewujudkan hal tersebut, sebab federalisme bukanlah totalitarianme yang membuat hidup manusia bergantung penuh bahkan dikawal oleh manusia yang lain. ${ }^{21}$ Analog Marc ini juga dapat dimaknai bahwa, suatu wilayah pemerintahan hendaknya tidak dikawal secara sepenuhnya oleh wilayah pemerintahan yang lain, walaupun kedudukannya secara hirarki lebih tinggi.

Secara singkat, perbedaan antara federalisme ideologis dan federalisme institusional sebagaimana dibahas di atas dapat dilihat dalam tabel 1 berikut.

\footnotetext{
${ }^{19}$ Ibid

${ }^{20}$ Ibid., hlm. 20.

${ }^{21}$ Alexander Marc., The Fundamentals Philosophy of Federalism, Le' Press, Paris, 1961, hlm. 14.
} 


\section{Tabel 1}

Perbedaan Federalisme Institusional dan Federalisme Ideologis

\begin{tabular}{|c|c|c|c|}
\hline No & Pembeda & Federalisme Institusional & Federalisme Ideologis \\
\hline 1. & Pengaturan & Diatur dalam Konstitusi & $\begin{array}{l}\text { Pengaturan dapat dibuat dalam } \\
\text { peraturan perundang-undangan yang } \\
\text { tingkatnya di bawah Konstitusi, seperti } \\
\text { UU. }\end{array}$ \\
\hline 2. & $\begin{array}{l}\text { Periode } \\
\text { Pengaturan }\end{array}$ & $\begin{array}{l}\text { Kebijakan tentang pembagian } \\
\text { kewenangan pusat dan daerah } \\
\text { dilaksanakan secara konsisten dan } \\
\text { berketerusan dalam tempo yang lama }\end{array}$ & $\begin{array}{l}\text { Dilaksanakan dalam tempo yang tidak } \\
\text { berlangsung lama, bahkan beberapa } \\
\text { bersifat sporadic }\end{array}$ \\
\hline 3. & Pengamalan & $\begin{array}{l}\text { Diamalkan di negara-negara yang } \\
\text { berbentuk federal saja }\end{array}$ & $\begin{array}{l}\text { Diamalkan oleh negara-negara federal } \\
\text { dan dapat pula diamalkan oleh negara- } \\
\text { negara berbentuk kesatuan dan } \\
\text { konfederal }\end{array}$ \\
\hline 4. & $\begin{array}{l}\text { Konstitusi yang } \\
\text { dimiliki }\end{array}$ & $\begin{array}{l}\text { Negara-negara bagian (negeri, } \\
\text { provinsi) memiliki konstitusi masing- } \\
\text { masing, selain konstitusi federal }\end{array}$ & $\begin{array}{l}\text { Daerah-daerah tidak mesti memiliki } \\
\text { konstitusi sendiri. Di negara kesatuan, } \\
\text { konstitusi hanya ada satu, iaitu di } \\
\text { tingkat pusat }\end{array}$ \\
\hline
\end{tabular}

Sumber : Diolah dari berbagai data oleh Penulis

\section{Ajaran Federalisme di Negara Kesatuan}

Federalisme sebagai suatu paham atau aliran sebagaimana disampaikan oleh kelompok ini dapat digunakan dalam konteks banyak negara sekarang ini, termasuk negara kesatuan (unity) seperti Inggris dan Indonesia.

Di Inggris, ajaran federalisme ideologis mulai dianut sejak 1997. Saat itu, pemerintah Inggris di bawah Perdana Menteri Tonny Blair melahirkan kebijakan devolusi kekuasaan (devolution of power). Kebijakan itu mengubah pola hubungan antara pemerintah pusat dengan daerah di Inggris yang berbentuk negara kesatuan itu.

Menurut Cusick, devolusi kekuasan dapat diartikan sebagai "the delegation of central government powers to subordinate units, these powers being exercised with some degree of autonomy though with ultimate power remaining with central government". Berdasarkan pemaknaan tersebut, yang diartikan dalam devolusi kekuasaan setidaknya mencakup dua unsur penting, yaitu : 1. Adanya delegasi kekuasaan dari pemerintah pusat kepada pemerintah daerah; dan, 2. Delegasi kekuasaan itu dicirikan dengan pemberian otonomi kepada pemerintah daerah tersebut. ${ }^{22}$

${ }^{22}$ http://www.thecep.org.uk/wordpress/devolution-for-england/ diakses terakhir 28 Agutus 2008. 
Secara teoritis, terdapat perbedaan antara devolusi kekuasaan dengan pembagian kekuasaan dalam negara federal. Pembagian kekuasaan dalam negara federal dicirikan dengan adanya pembagian kekuasaan antara pemerintah pusat dan daerah yang diatur secara tegas dalam Konstitusi. Devolusi kekuasaan memberikan pembagian kekuasaan antara pemerintah pusat dengan daerah melalui kebijakan yang diberikan oleh pemerintah pusat.

Sejarah berlakunya devolusi kekuasaan di Inggris dimulai dengan adanya konflik antara pemerintah pusat Inggris dan beberapa daerah, seperti Scotlandia, Wales dan Irlandia Utara. Daerah-daerah tersebut merasa memiliki karakteristik yang khas dan berbeda dibanding kebanyakan daerah di Inggris lainnya. Perbedaan itulah yang dijadikan alasan untuk memisahkan diri dari Inggris.

Konflik yang terus berpanjangan tersebut membuat Prescout, seorang anggota Perlemen dari Partai Buruh mengeluarkan gagasan untuk memberikan devolusi kekuasaan kepada daerah-daerah tersebut pada Pemilihan Umum tahun 1997. Isu itu ditanggapi positif oleh beberapa pihak dan akhirnya menempatkan Prescout sendiri sebagai Wakil Perdana Menteri Inggris pada masa itu. ${ }^{23}$

Mulai saat itulah pemerintahan Inggris menerapkan devolusi keuasaan dan mulai meninggalkan sistem negara kesatuan yang tulen. Oleh beberapa pihak, devolusi kekuasaan di Inggris melahirkan sistem quasi-federalisme di negara itu. Bentuk-bentuk devolusi kekuasaan di Inggris sekarang ini berbeda antara satu daerah dengan daerah lainnya.

Di Scotlandia misalnya, bentuk devolusi kekuasaan di provinsi ini berupa devolusi legislatif dengan terbentuknya Parlemen Scotlandia. Devolusi kekuasaan di Scotlandia diimplementasikan dengan memberikan kewenangan terhadap pelbagai kebijakan kepada Parlimen Nasional, yaitu kebijakan di bidang luar negara, stabilitas ekonomi, kebijakan di bidang keuangan, pertahanan dan kemananan nasional, kebijakan tentang pasar bersama (common market), serta kebijakan di bidang hukum perburuhan dan keamanan sosial. ${ }^{24}$

Parlemen Scotlandia diberikan kekuasaan untuk membuat peraturan di tingkat lokal dalam bidang kesehatan, pendidikan, latihan, pemerintahan lokal,

\footnotetext{
${ }^{23}$ http://findarticles.com/p/articles/mi_qn4156/is_20070527/ai_n19184167 diakses terakhir 28 Agustus 2008.

${ }^{24}$ Philip, S., Scotland's Parliament: Devolution, Tthe Media And Political Culture, The ARENA Working Paper Series, London, 1998, hlm. 34.
} 
pengangkutan, pekerjaan sosial, perumahan, pertumbuhan ekonomi, lingkungan hidup, pertanian. perikanan dan kehutanan, olahraga, seni, dan pelbagai kebijakan lain diluar kewenangan pemerintahan pusat Inggris.

Selain di Scotlandia, devolusi kekuasaan juga dipraktikkan di Wales, Irlandia Utara dan Kota London. Di Wales bentuk devolusinya berupa devolusi eksekutif yang dicirikan dengan adanya Pemilihan Assembly of Wales - semacam pimpinan eksekutif daerah yang jumlahnya banyak -.

Assembly of Wales sendiri beranggotakan 60 (enampuluh) orang dan memiliki kewenangan untuk menata tata kelola pemerintahan di Wales dalam bidang: Bahasa Welsh, seni dan pusaka, industri dan pelatihan, pembangunan ekonomi, layanan sosial, pertanian, lingkungan hidup, pendidikan, perencanaan, perumahan, kesehatan dan pembinaan jalan raya. Anggota Assembly tersebut sebanyak 40 (empatpuluh)orang dipilih melalui Pemilihan Umum daan 20 (duapuluh) orang lainnya melalui penunjukan. ${ }^{25}$

Di Irlandia Utara, devolusi kekuasaan yang dimulai dengan perundingan segitiga pada 1997 antara pemerintah Inggris, Kerajaan Irlandia dan partai-partai di Irelandia Utara difasilitasi oleh bekas senator US George Mitchell. Perundingan itu berhasil melahirkan kesepakatan pada April 1998 yang dikenal dengan nama Belfast Agreement. Perjanjian itu digagas, karena selama ini Ireland Utara diklaim sebagai bagian dari Republik Irlandaia, sedangkan oleh Inggris ia juga diklaim sebagai wilayahnya.

Devolusi kekuasaan di Irlandia Utara melahirkan constitutional devolution, yaitu pembuatan Konstitusi sendiri di Irlandia Utara yang melibatkan Republik Irlandia dalam pembuatannya. Kesepakatan Belfast itu juga melahirkan Dewan Rakyat Irlandia Utara yang memiliki kewenangan di bidang eksekutif. Dewan Rakyat itu terdiri dari partai-partai yang ada di Irlandia Utara. ${ }^{26}$

Praktik devolusi kekuasaan lain di Inggris berada di Kota London. Di ibukota Inggris ini, devolusi dilakukan melalui devolusi eksekutif yang telihat dari adanya mekanisme Pemilihan Dewan Rakyat (Assembly) London dan Mayor (semacam Walikota) London secara langsung. Di region-region di Inggris fungsi Mayor adalah

\footnotetext{
${ }^{25}$ Hazell, R., The State And the Nations: The First Year of Devolution in the Inggris, Imprint Academic, London, 2000, hlm. 124.

${ }^{26}$ Dearlove, J dan Saunders, P. 2008. Introduction to British Politics dalam http://www.polity.co.uk/britpol/ devolution.htm diakses terakhir pada 28 Agustus 2008
} 
untuk mengkoordinasikan kebijakan yang dibuat untuk regionnya. Sedangkan fungsi Dewan Rakyat pada region ialah sebagai tempat berdiskusi berbagai kebijakan regional, perencanaan dan strategi yang prinsipal, pembangunan ekonomi dan pendidikan tinggi, serta pengangkutan.

Pada region-region di Inggris, anggota Dewan Rakyat 70\% dipilih dari perwakilan pemerintahan lokal dan sebagian kecil lainnya dipilih berdasarkan perwakilan kelompok masyarakat daripada region tersebut. Di London dengan adanya devolusi kekuasaan, seluruh anggota Dewan Rakyat dipilih langsung oleh penduduk London. ${ }^{27}$

Dalam konteks implementasi devolusi kekuasaan di Inggris, terdapat perbedaan mendasar antara istilah devolusi legislatif dan eksekutif. Devolusi kekuasaan legislatif dimaknai sebagai kekuasaan yang dimiliki pemerintah daerah (provinsi, region) untuk membuat peraturan perundang-undangan di daerah setempat. Dalam devolusi legislatif, Dewan Rakyat yang dipilih memiliki kekuasaan untuk membuat sendiri peraturan yang berkaitan dengan daerahnya. Sedangkan dalam devolusi eksekutif secara relatif kekuasaan yang dimiliki lemah, di mana kekuasaan untuk membuat peraturan perundang-undangan masih berada di Parlimen Nasional Inggris yang popular disebut sebagai Westminster.

Praktek lain teori dari federalisme ideologis di negara kesatuan adalah adanya kebijakan otonomi daerah di Indonesia. Sebagaimana disebutkan dalam pendahuluan di atas, otonomi di Indonesia melahirkan ambiguistik bentuk negara dalam kaitan hubungan antara pemerintah pusat dan daerah oleh sebagian pihak.

Ambiguistik itu lahir karena dalam ketentuan Pasal 1 ayat (3) UUD 1945 dinyatakan bahwa " Indonesia adalah negara kesatuan yang berbentuk Republik". Namun di pihak yang lain sebagaimana disebutkan sebelumnya, UUD 1945 setelah amandemen juga menegaskan adanya otonomi yang seluas-luasnya kepada provinsi, kabupaten/kota sebagaimana ditegaskan dalam Pasal 18 ayat (5) UUD 1945. Namun, ambiguistik itu dapat dipahami dengan mengacu pada teori federalisme ideologis yang tak mengharuskan danya relasi positif antara bentuk negara kesatuan dengan pemusatan kekuasaan secara ketat dalam kaitan hubungan pusat dan daerah.

Apabila di Inggris devolusi kekuasaan hanya dilakukan di beberapa daerah, maka otonomi daerah di Indonesia diberlakukan di seluruh wilayah negara ini. Di

${ }^{27}$ http://www.ucl.ac.uk/consitution-unit diakses terakhir 29 Agustus 2008. 
beberapa provinsi di Indonesia, seperti Aceh dan Papua bahkan diberikan otonomi khusus.

Perbedaan lain antara devolusi kekuasaan di Inggris dengan otonomi daerah di Indonesia ialah, di Inggris devolusi kekuasaan dipraktekkan melalui legislative devolution ataupun executive devolution secara berbeda-beda di beberapa daerah yang diberikan devolusi tersebut. Sedangkan di Indonesia, otonomi daerah dilakukan dengan memberikan pengaturan yang sama berdasarkan undang-undang bagi setiap daerah-daerahnya, kecuali kebijakan tentang otonomi khusus sebagaimana disebutkan di atas.

\section{Konsep Dasar Partai Politik Lokal untuk Indonesia}

Selain adanya landasan teoritikal berupa federalisme ideologis yang diserap Indonesia pasca otonomi daerah, alasan lain dari perspektif hukum tata negara yang dapat dijadikan dasar ide pembentukan partai politik lokal ini ialah adanya pertentangan antara pengaturan dalam beberapa UU terkait sebagaimana disinggung dalam pendahuluan tulisan ini.

Pertentangan tersebut dapat dilihat dari perbedaan substansi pengaturan dalam UU No. 2 Tahun 2008 tentang Partai Politik jo UU No. 10 Tahun 2008 tentang Pemilu yang mensyaratkan Partai Politik bersifat nasional dengan ketentuan yang terdapat dalam UU No. 32 Tahun 2004 tentang Pemerintahan Daerah yang menegaskan adanya otonomi politik bagi daerah.

Pertentangan tersebut dapat diselesaikan dengan memenuhi amanah UU No. 32 Tahun 2004 terkait dengan otonomi politik tadi. Pembentukan partai politik lokal sebagai antitesa dari sistem kepartaian yang bersifat nasional sekarang ini dapat menjadi satu rujukan ke arah itu.

Dalam tulisan ini, akan dikemukakan tiga mendasar terkait pembentukan partai politik lokal tersebut di Indonesia, yaitu Pertama, kedudukan partai politik lokal terkait kewenangan otonomi daerah, Kedua, hubungan partai politik lokal, partai politik nasional dan pemilu, serta yang ketiga; hubungan antar partai politik lokal ke depan.

\section{Partai Politik Lokal dan Otonomi Daerah}

Persoalan paling dasar dalam pembentukan konsep tentang partai politik lokal hubungannya dengan otonomi ialah dimanakah partai politik lokal itu diletakkan 
dalam struktur pemerintahan daerah di Indonesia. Apakah ia diletakkan di tingkat provinsi atau di tingkat kabupaten/kota?

Berdasarkan ketentuan terkait kewenangan provinsi, kabupaten/kota dalam UU No. 32 Tahun 2004, kedudukan provinsi dalam struktur pemerintahan mempunyai kewenangan untuk melakukan koordinasi, mengawasi dan membina pemerintahan kabupeten/kota di wilayahnya.

Dalam konteks kewenangan otonomi itu, pemerintahan provinsi juga mempunyai kewenangan untuk menangani pelbagai urusan yang berkaitan dengan urusan lintas kabupaten/kota. Berdasarkan hal itulah, konsep partai politik lokal k edepan akan lebih efektif jika diletakkan di provinsi. Adapun partai-partai yang ada di kabupaten/kota merupakan cabang dari partai yang berpusat di provinsi tersebut. Hal ini dibuat agar, partai-partai di kabupaten/kota yang akan menempatkan kadernya pada institusi legislatif dan eksekutif di kabupaten/kota dapat dimonitor oleh partai pusatnya di provinsi dan dapat menjalankan urusan otonomi secara selaras.

Adapun secara singkat konsep partai politik lokal yang dirancang dalam hubungannya dengan struktur pemerintahan daerah dan kebijakan otonomi tersebut sebagaimana digambarkan dalam bagan 1 berikut.

\section{Bagan 1}

Struktur Partai Politik Lokal
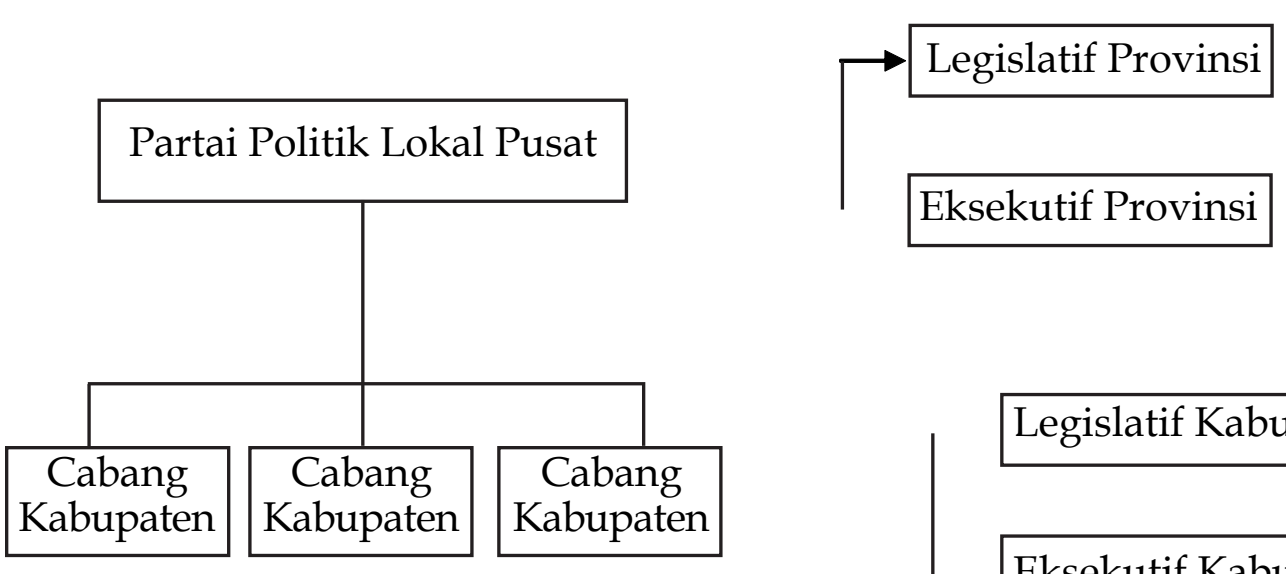

Legislatif Kabupaten

Eksekutif Kabupaten

Berdasar bagan tersebut dapat dilihat bahwa yang dimaksudkan dengan partai politik lokal, ialah partai politik yang berkedudukan dalam wilayah provinsi dan memiliki cabang-cabang di kabupaten/kota dalam wilayah provinsi tersebut. 
Partai politik lokal yang didesain ke depan hanya memperbolehkan suatu partai didirikan dalam satu provinsi tertentu saja. Hal ini disebabkan agar kehadirannya untuk memperkuat kebijakan otonomi daerah, dimana kebijakan itu sendiri diberikan kepada masing-masing daerah untuk mengurusi pelbagai kekhasan daerahnya masing-masing melalui urusan pilihan pemerintahan sebagaimana diatur dalam UU No. 32 Tahun 2004.

\section{Partai Politik Lokal, Partai Politik Nasional, dan Pemilu}

Secara yuridis ketatanegaraan, sesungguhnya telah terjadi pemisahan antara partai politik lokal dan partai politik nasional dalam konteks hak dan kewajiban yang mereka lakukan dalam beberapa hal, Pertama, dalam hal mengajukan calon anggota parlemen (DPR/DPRD) dalam Pemilu sebagaimana diatur dalam Pasal 52 UU No. 2 Tahun 2008.

Kedua, dalam konteks pengawasan terhadap anggota DPR/D juga terdapat pemisahan kewenangan antara kedunya sebagaimana ditegaskan dalam UU No. 22 Tahun 2003 tentang Susunan dan Kedudukan MPR, DPR, DPD dan DPRD, khususnya dalam hal pemecatan anggota DPR/D dimaksud melalui mekanisme pergantian antar waktu (PAW). Selain dua hal itu, hal yang ketiga ialah kewenangan partai untuk memberhentikan Ketua DPR/D yang berasal dari partainya. ${ }^{28}$

Berdasarkan konstruksi hubungan antara partai politik di tingkat pusat dengan partai politik di daerah sekarang ini, maka konsep partai politik lokal ke depan hendaknya mempertegas pemisahan kewenangan yang sudah ada dalam pelbagai peraturan perundang-undangan tersebut.

Konsep partai politik lokal kedepan hendaknya juga secara tegas menempatkan partai politik lokal dan partai politik nasional sebagai dua jenis partai yang berbeda. Pemisahan antara kedua jenis partai tersebut juga dimaksudkan untuk memperkuat dasar otonomi daerah di bidang politik sebagaimana tujuan penulisan ini. Adapun konsep pembagian sistem kepartaian di Indonesia setelah lahirnya partai politik loklal nantinya dapat dilihat dalam bagan 2 berikut.

${ }^{28}$ Lihat Pasal 23 UU No. 22 Tahun 2003 tentang Susduk MPR, DPR, DPD dan DPRD. 


\section{Bagan 2}

Pembagian Sistem Kepartaian di Indonesia

Setelah Lahirnya Partai Politik Lokal

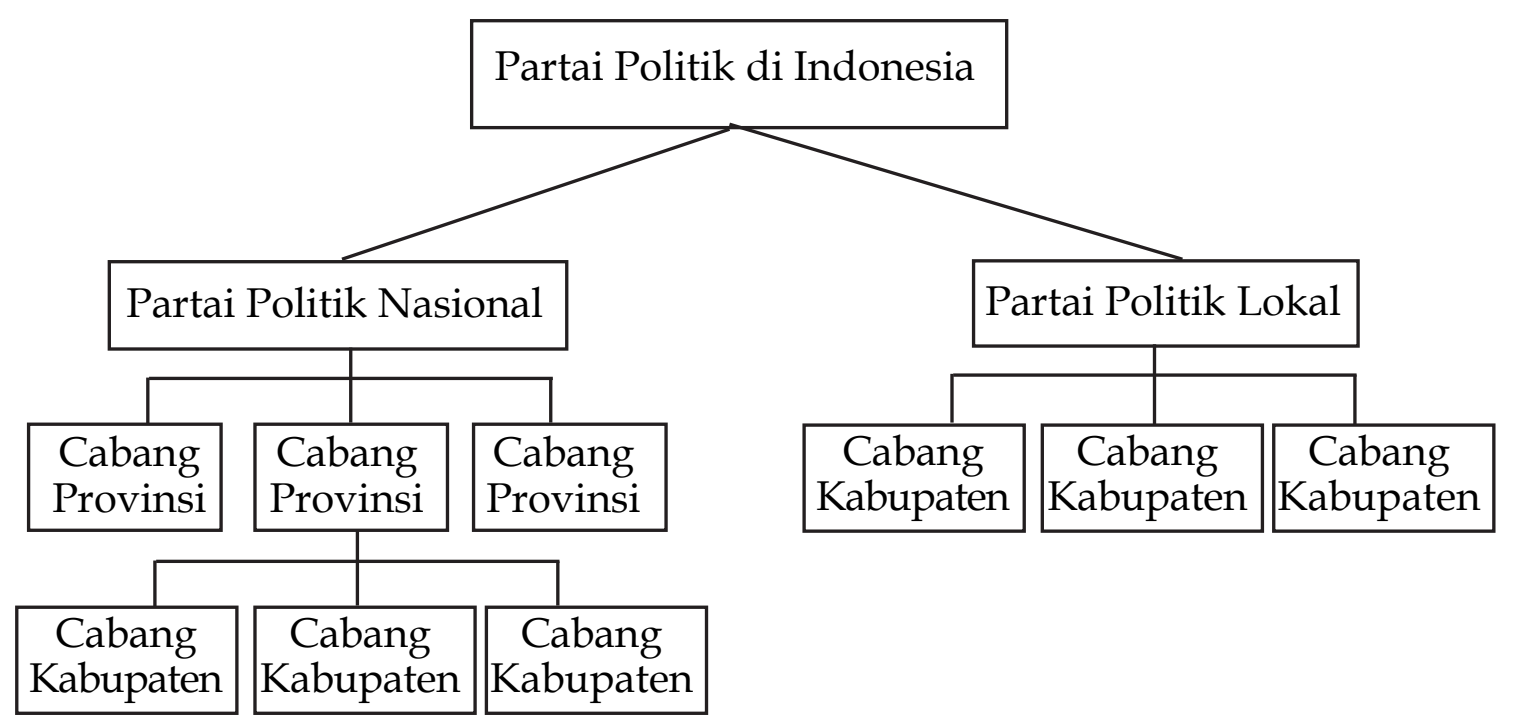

Berdasarkan bagan di atas dapat dilihat partai politik nasional berpusat di tingkat nasional dan mempunyai cabang-cabang di tingkat provinsi sampai di tingkat kabupaten/kota. Adapun partai politik lokal berpusat di tingkat provinsi. Ia mempunyai cabang di tingkat kabupaten/kota dalam wilayah provinsinya saja sebagaimana konsep struktur partai berkaitan dengan kewenangan otonomi sebelumnya.

Kedudukan cabang-cabang partai nasional di tingkat provinsi dan kabupaten berfungsi untuk mensosialisasikan pelbagai program kerja partai nasional ke berbagai lapisan masyarakat di daerah. Khusus terkait Pemilu, cabang-cabang partai nasional di tingkat daerah ini sangat memegang peranan penting untuk melakukan kampanye sampai ke lapisan paling bawah. Di antara kedua cabang partai itu tidak akan terjadi tumpang tindih peranan, sebab mereka dari awal telah didesain dengan peranan dan lahan garap berbeda.

Pemisahan kedua jenis partai tersebut akan menghadirkan berbagai akibat, termasuk dalam konteks Pemilu. Untuk itu, dalam pembentukan partai politik lokal nantinya didesain agar tercipta pembagian yang tegas diantara keduanya sebagaimana disebutkan sebelumnya, termasuk dalam pemisahan dalam konteks Pemilu seperti dapat dilihat dalam bagan 3 berikut. 
Bagan 3

Konsep Pemilu Akibat Lahirnya Partai Politik Lokal
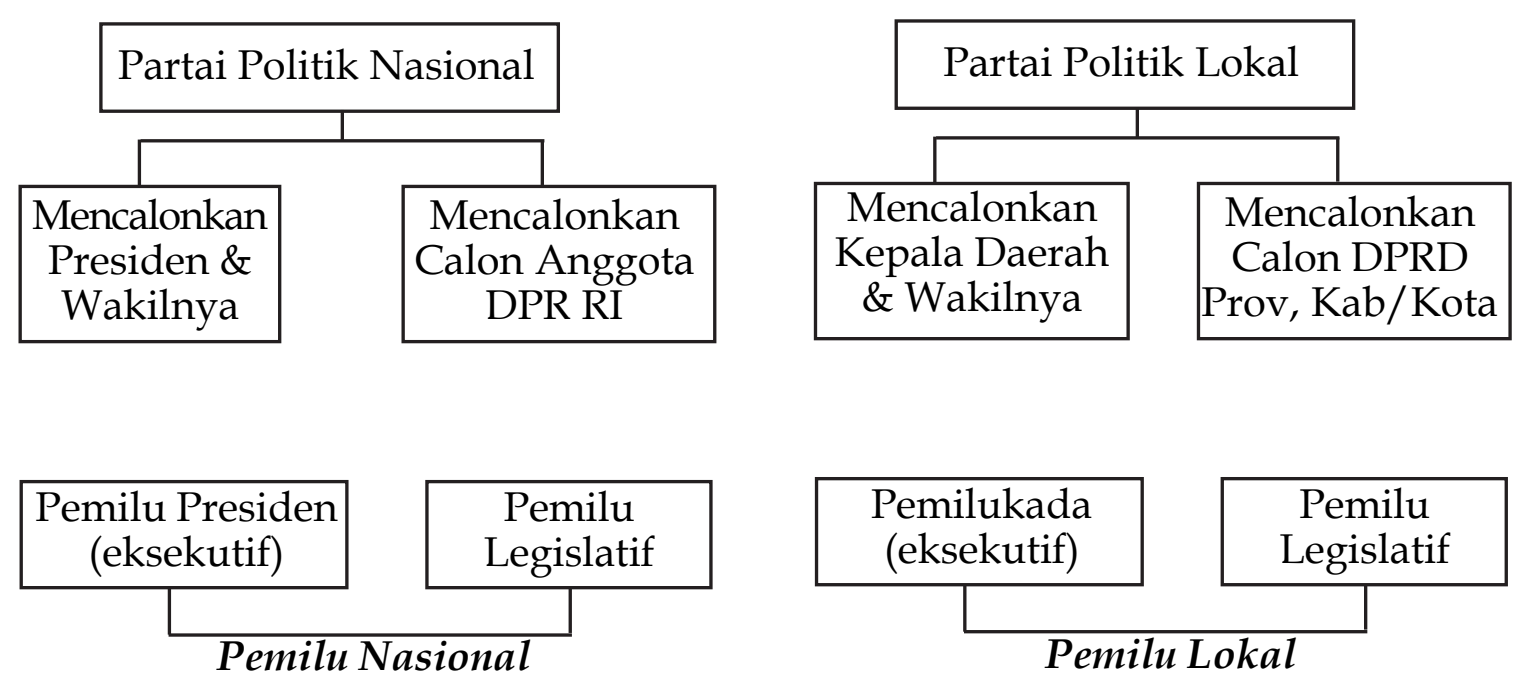

Berdasarkan bagan di atas, dapat dilihat bahawa konsep tentang keikutsertaan partai politik nasional dan partai politik lokal dalam Pemilu dapat dipisahkan kepada dua jenis Pemilu, yaitu Pemilu nasional dan Pemilu lokal. Pemilu nasional hanya dapat diikuti oleh partai politik nasional, sebaliknya Pemilu lokal hanya dapat diikuti oleh partai politik lokal.

\section{Relasi antar Partai Politik Lokal}

Permasalahan lain yang mesti dibahas dalam desain partai politik lokal ini ialah hubungan antara partai politik lokal yang satu dengan yang lainnya. Hubungan itu sangat mungkin terjadi dalam dua bentuk yaitu, hubungan positif dan negatif.

Dalam konteks yang positif, hubungan antara partai politik lokal dapat hadir pada saat mereka membentuk koalisi. Sedangkan dalam konteks yang negatif, hubungan keduanya dapat saja berupa perselisihan yang secara yuridis mesti dicarikan jalan keluarnya. Hubungan antara sesama partai politik lokal, baik positif, maupun negatif tersebut dapat dilihat dalam bagan 4 berikut. 